\title{
Theoretical Study of the Structure and Vibrational Spectrum of [Zn(2-Aminothiazole) $\left.{ }_{2} \mathrm{Cl}_{2}\right]$
}

\author{
Rumyana Yankova \\ Department of Inorganic and Analytical Chemistry, Assen Zlatarov University, Bourgas, Bulgaria \\ Email: $\underline{r \text { iankova@yahoo.com }}$
}

Received 19 August 2015; accepted 5 September 2015; published 10 September 2015

Copyright (C) 2015 by author and OALib.

This work is licensed under the Creative Commons Attribution International License (CC BY). http://creativecommons.org/licenses/by/4.0/

(c) (i) Open Access

\section{Abstract}

The geometry optimization of [ $\left.\mathrm{Zn}(2 \text {-Aminothiazole })_{2} \mathrm{Cl}_{2}\right]$ complex was done in gas and in water phase by $a b$ initio, Hartree-Fock (HF) and Density Functional Theory (DFT/B3LYP) methods with 6-31G(d, p) basis set. A complete vibrational assignment was provided for the observed IR spectra. The bond orders and the electronic properties of the complex were calculated. The calculated highest occupied molecular orbital (HOMO) and lowest unoccupied molecular orbital (LUMO) with frontier orbital gap were presented. The electrostatic potential was calculated in order to investigate the reaction properties of the molecule. The important thermo-dynamical parameters were also reported.

\section{Keywords}

[Zn(2-Aminothiazole) ${ }_{2} \mathrm{Cl}_{2}$ ] Complex, Quantum Chemical Calculations, Geometry Optimization, Electronic Properties

\section{Subject Areas: Analytical Chemistry}

\section{Introduction}

The coordination compounds of ligands containing nitrogen and sulphur as the donor atoms exhibit a wide spectrum of biological activities. The thiazoles compounds have a number of characteristic pharmacological features, such as relative stability and ease of starting materials. The first syntheses of the thiazolic ring were made at the end of the nineteenth century. The derivatives of thiazoles soon constituted an important part of heterocyclic chemistry. Vitamin B1, penicillin and coenzyme cocarboxylase contain the thiazole ring. Some derivatives of the 2-Aminothiazoles are used as fungicides, pesticides, and bacteriocides. 2-Aminothiazoles are known mainly as biologically active compounds with a broad range of activity and as intermediates in the synthesis of antibio- 
tics and dyes [1]. The biological activity of these compounds may be connected to their ability [2] [3] to form complexes with metal ions. Metal complexes with these ligands are becoming important as biochemical and antimicrobial reagents [4] [5].

The aim of the present work is using quantum chemical calculations to determine the geometry and electronic structure of [ $\left.\mathrm{Zn}(2-\mathrm{Aminothiazole})_{2} \mathrm{Cl}_{2}\right]$ complex, to provide vibrational assignment for the IR spectra and investigate quantum chemical parameters, such as highest occupied, lowest unoccupied molecular orbital energy levels, energy gap, electrostatic potential, and atomic charges.

\section{Computational Methods}

The full optimization of [ $\left.\mathrm{Zn}(2 \text {-Aminothiazole })_{2} \mathrm{Cl}_{2}\right]$ complex was carried out by the DFT and $a b$ initio HartreeFockmethods using the Gaussian 03 program [6] package employing 6-31G(d, p) basis setand Becke's three parameter (local, nonlocal, Hartree-Fock) hybrid exchange functional with Lee-Yang-Parrcorrelation functional (B3LYP) [7]-[9]. All calculations were converged to $10^{-8}$ a.u. Vibration frequencies were also calculated to the structure with optimized geometry and no imaginary frequencys were obtained, sothe stationary points correspond to the minima of the potential energy surface.

An effective method for studying the reaction behavior of molecules is the measuring of their electrostatic potential. The electrostatic potential of [ $\mathrm{Zn}(2 \text {-Aminothiazole })_{2} \mathrm{Cl}_{2}$ was calculated by DFT method at the B3LYP level with 6-31G(d, p) basis set. In order to characterize the electronic population on each atomic centre a Mulliken population analysis [10] was carried out for [Zn(2-Aminothiazole $)_{2} \mathrm{Cl}_{2}$ ].

To take into account the effect ofthe solvent by self-consistent reaction field (SCRF) the method of Onsager was used [11]. The software packages HyperChem 5.0 [12] and Molekel 5.4 [13] were used for data preparation and visualization ofthe results.

\section{Results and Discussion}

\subsection{Geometry Optimization}

The visualization of the optimized geometrical structure and atomic labeling of [ $\mathrm{Zn}\left(2\right.$-Aminothiazole $\left.{ }_{2} \mathrm{Cl}_{2}\right]$ complex are presented in Figure 1.

The results obtained from the geometry optimization of [ $\left.\mathrm{Zn}(2-\mathrm{Aminothiazole})_{2} \mathrm{Cl}_{2}\right]$ in gas-phase and in waterphase cannot be verified experimentally. The agreement between the optimized geometry (in gas and in water phase) and the experimental crystal structure [14] (insolid phase and in the presence of intermolecular interactions) is excellent showing that the geometry optimization almost exactly reproduces the experimental conformation as one can expect. The optimized structural parameters (bond lengths, bondangles, dihedral angles) of [Zn(2-Aminothiazole $)_{2} \mathrm{Cl}_{2}$ ] were compared with the experimental one and are listed in Table 1.

Quantum chemical calculations provide the ability to calculate the net atomic charges $(q)$, which are localized at the corresponding atoms as a result of the redistribution of the electrons in the molecule. Though they are not connected with physical properties and cannot be observed experimentally, they allow the understanding of the distribution of the electronic density in a system of connected atoms and predict some chemical properties of the

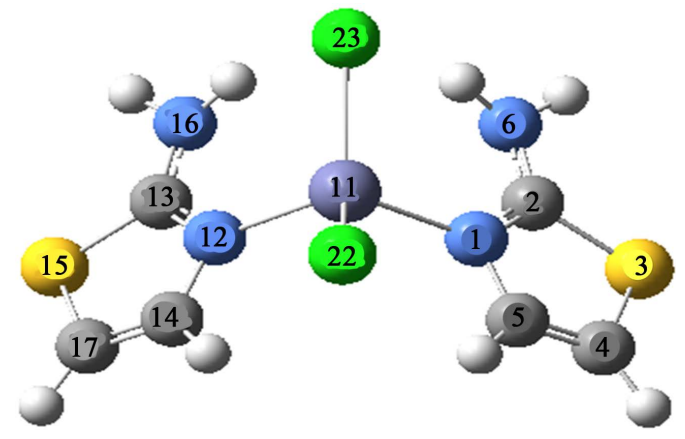

Figure 1. Optimized geometrical structure and atomic labeling of [Zn(2-Aminothiazole) ${ }_{2} \mathrm{Cl}_{2}$ ]. (C-atoms are in gray, $\mathrm{N}$-atoms are in blue, $\mathrm{S}$-atoms are in yellow, $\mathrm{Cl}$-atoms are in green and $\mathrm{Zn}$-atom is violet). 
Table 1. Optimized geometrical parameters of [Zn(2-Aminothiazole $\left.)_{2} \mathrm{Cl}_{2}\right]$ complex.

\begin{tabular}{|c|c|c|c|c|}
\hline Parameters & $\begin{array}{l}\text { In solid phase } \\
\text { Exp. [14] }\end{array}$ & $\begin{array}{l}\text { In gas phase } \\
\text { HF/6-31G(d, p) }\end{array}$ & $\begin{array}{c}\text { In gas phase } \\
\text { B3LYP/6-31G(d, p) }\end{array}$ & $\begin{array}{c}\text { In water phase } \\
\text { B3LYP/6-31G(d, p) }\end{array}$ \\
\hline \multicolumn{5}{|l|}{ Bond length (Á) } \\
\hline $\mathrm{Zn}-\mathrm{Cl}^{22}$ & 2.239 & 2.256 & 2.232 & 2.255 \\
\hline $\mathrm{Zn}-\mathrm{Cl}^{23}$ & 2.255 & 2.314 & 2.320 & 2.322 \\
\hline $\mathrm{Zn}-\mathrm{N}^{1(12)}$ & 2.024 & 2.116 & 2.054 & 2.039 \\
\hline$S^{3(15)}-C^{2(13)}$ & 1.726 & 1.738 & 1.758 & 1.755 \\
\hline$S^{3(15)}-C^{4(17)}$ & 1.712 & 1.746 & 1.754 & 1.753 \\
\hline $\mathrm{C}^{2(13)}-\mathrm{N}^{6(16)}$ & 1.337 & 1.339 & 1.352 & 1.346 \\
\hline $\mathrm{N}^{1(12)}-\mathrm{C}^{2(13)}$ & 1.316 & 1.300 & 1.324 & 1.328 \\
\hline $\mathrm{N}^{1(12)}-\mathrm{C}^{5(14)}$ & 1.384 & 1.392 & 1.391 & 1.391 \\
\hline$C^{4(17)}-C^{5(14)}$ & 1.332 & 1.328 & 1.350 & 1.351 \\
\hline \multicolumn{5}{|l|}{ Bond angle (grad) } \\
\hline $\mathrm{Cl}^{22}-\mathrm{Zn}-\mathrm{Cl}^{23}$ & 113.5 & 127.3 & 125.8 & 120.9 \\
\hline $\mathrm{Cl}^{23}-\mathrm{Zn}-\mathrm{N}^{1(12)}$ & 108.5 & 105.8 & 104.7 & 106.6 \\
\hline $\mathrm{Cl}^{22}-\mathrm{Zn}-\mathrm{N}^{1(12)}$ & 106.5 & 104.8 & 105.2 & 107.9 \\
\hline $\mathrm{N}^{1}-\mathrm{Zn}-\mathrm{N}^{12}$ & 109.6 & 107.1 & 111.1 & 106.1 \\
\hline$C^{2(13)}-S^{3(15)}-C^{4(17)}$ & 89.1 & 89.1 & 89.2 & 89.2 \\
\hline $\mathrm{Zn}-\mathrm{N}^{1(12)}-\mathrm{C}^{2(13)}$ & 128.5 & 130.3 & 129.5 & 128.5 \\
\hline $\mathrm{Zn}-\mathrm{N}^{1(12)}-\mathrm{C}^{5(14)}$ & 120.7 & 118.6 & 119.0 & 119.6 \\
\hline $\mathrm{C}^{2(13)}-\mathrm{N}^{1(12)}-\mathrm{C}^{5(14)}$ & 111.0 & 111.1 & 111.5 & 111.3 \\
\hline$S^{3(15)}-C^{2(13)}-N^{6(16)}$ & 121.6 & 121.1 & 122.1 & 122.2 \\
\hline$S^{3(15)}-C^{2(13)}-N^{1(12)}$ & 113.3 & 114.0 & 113.4 & 113.6 \\
\hline $\mathrm{N}^{6(16)}-\mathrm{C}^{2(13)}-\mathrm{N}^{1(12)}$ & 125.0 & 124.9 & 124.5 & 124.3 \\
\hline$N^{1(12)}-C^{5(14)}-C^{4(17)}$ & 115.7 & 116.9 & 115.9 & 115.9 \\
\hline$S^{3(15)}-C^{4(17)}-C^{5(14)}$ & 110.7 & 109.7 & 110.0 & 110.1 \\
\hline \multicolumn{5}{|l|}{ Dihedral angle (grad) } \\
\hline $\mathrm{C}^{5(14)}-\mathrm{N}^{1(12)}-\mathrm{Zn}-\mathrm{Cl}^{22}$ & - & 23.97 & 24.57 & 30.03 \\
\hline $\mathrm{C}^{2(13)}-\mathrm{N}^{1(12)}-\mathrm{Zn}-\mathrm{Cl}^{23}$ & - & 20.70 & 20.79 & 28.83 \\
\hline $\mathrm{C}^{5(14)}-\mathrm{N}^{1(12)}-\mathrm{Zn}-\mathrm{N}^{12(1)}$ & - & 87.02 & 88.69 & 85.40 \\
\hline
\end{tabular}

molecules. The nitrogen atoms exhibit their electro negative nature as expected. The net atomic charges, calculated by Mulliken and the order of the bonds in the investigated compound are presented in Table 2. Obviously, the thiazole bond orders are in the range 1.218 - 1.774. These bond orders values suggest a relatively strong aromatic character for the five-membered ring of thiazole.

\subsection{Molecular Electrostatic Potential Analysis}

The presence of amino groups leads to the electronic coupling between ring electrons and nitrogen lone pair electrons which provides stabilization to the molecular structure. Hence it is important to study the electrostatic 
Table 2. Mulliken atomic charges and bond orders of [ $\mathrm{Zn}(2-\text { Aminothiazole })_{2} \mathrm{Cl}_{2}$ ].

\begin{tabular}{cccc}
\hline Atom & Mulliken atomic charges & Bond & Bond order \\
\hline $\mathrm{Zn}$ & 0.765 & $\mathrm{Zn}-\mathrm{Cl}^{22}$ & 0.989 \\
$\mathrm{Cl}^{22}$ & -0.509 & $\mathrm{Zn}-\mathrm{Cl}^{23}$ & 0.815 \\
$\mathrm{Cl}^{23}$ & -0.527 & $\mathrm{Zn}-\mathrm{N}^{1(12)}$ & 0.542 \\
$\mathrm{~N}^{1(12)}$ & -0.569 & $\mathrm{~S}^{3(15)}-\mathrm{C}^{2(13)}$ & 1.246 \\
$\mathrm{~N}^{6(16)}$ & -0.612 & $\mathrm{~S}^{3(15)}-\mathrm{C}^{4(17)}$ & 1.218 \\
$\mathrm{~S}^{3(15)}$ & 0.248 & $\mathrm{C}^{2(13)}-\mathrm{N}^{6(16)}$ & 1.407 \\
$\mathrm{C}^{2(13)}$ & 0.330 & $\mathrm{~N}^{1(12)}-\mathrm{C}^{2(13)}$ & 1.581 \\
$\mathrm{C}^{4(17)}$ & -0.323 & $\mathrm{~N}^{1(12)}-\mathrm{C}^{5(14)}$ & 1.280 \\
$\mathrm{C}^{5(14)}$ & 0.163 & $\mathrm{C}^{4(17)}-\mathrm{C}^{5(14)}$ & 1.774 \\
\hline
\end{tabular}

potential distribution in the molecule. The molecular electrostatic potential is a property that the electrons and nuclei of a molecule create at each point an electrical potential in the surrounding space [15]. Electrostatic potential provides very useful information to explain hydrogen bonding, reactivity and structure-activity relationship of molecules and correlates with dipole moment, electro negativity, partial charges and site of chemical reactivity of the molecule. It gives a visualization to understand the relative polarity of a molecule. The regions with negative electrostatic potential, correspond to the areas of high electron density representing a strong attraction between the proton and the points, on the molecular surface have the brightest red color. The positive valued regions, areas of lowest electron density, have deep blue color indicating the regions of maximum repulsion. The electron density isosurface onto which the electrostatic potential surface was mapped is shown in Figure 2 for [ $\mathrm{Zn}(2-\mathrm{Aminothiazole})_{2} \mathrm{Cl}_{2}$ ]. It is visible that the region of the most negative electrostatic potential is spread over the $\mathrm{Cl}^{22}$. Regions of most positive electrostatic potential is over the amino groups.

The molecular electrostatic potential is widely used as a reactivitymap displaying most probable regions for the electrophilicattack of charged point-like reagents on organic molecules.The negative (red color) regions of electrostatic potential arerelated to electrophilic reactivity and the positive (bluecolor) onesto nucleophilic reactivity.

\subsection{HOMO-LUMO Analysis}

The frontier orbitals (highest occupied molecular orbital-HOMO) and (lowest unoccupied molecular orbitalLUMO) are very important indefining its reactivity. The HOMO exhibits the ability to donate an electron and LUMO as an electron acceptor serves the ability to obtain an electron. The HOMO and LUMO energy calculated by B3LYP/6-31G(d, p) level of theory show the energy gap which reflects the chemical activity of the molecule (Figure 3).

High values of $E_{\text {номо }}$ have a tendency of themolecule to donate electrons to appropriate acceptor molecules with low energy, empty molecular orbitals. The energy of the lowest unoccupied molecular orbital indicates the ability of themolecule to accept electrons. The lower value of $E_{\text {LUMO }}$, the more probable it is that the molecule wouldaccept electrons. Consequently, concerning the value of theenergy of the gap $\Delta E_{\text {LUMO-Hомо, larger values }}$ ofthe energy difference will provide low reactivity to achemical species. Lower values of the energy difference will render good inhibition efficiency, because the energy toremove an electron from the last occupied orbital will below. The results for the calculations of the ionization potential $(I)$ and the electron affinity $(A)$ by application of the Koopmans' theorem [16] are shown. According to the Hartree-Fock theorem, the frontier orbital energies are given by: $I=-E_{\mathrm{HOMO}}=617.491 \mathrm{~kJ} / \mathrm{mol} ; A=-E_{\mathrm{LUMO}}=86.852 \mathrm{~kJ} / \mathrm{mol}$. This theorem establishes a relation between the energies of the HOMO and the LUMO and the ionization potential and the electron affinity, respectively. Although no formal proof of this theorem exists within DFT, its validity is generally accepted. Electro negativity $(\chi)$, chemical potential $(\mu)$ and global hardness $(\eta)$, their operational and approximate definitions for $\left[\mathrm{Zn}(2 \text {-Aminothiazole })_{2} \mathrm{Cl}_{2}\right]$ are: $\chi=-\mu=(I+A) / 2=352.172 \mathrm{~kJ} / \mathrm{mol} ; \eta=(I-A) / 2=265.320$ $\mathrm{kJ} / \mathrm{mol}$. 


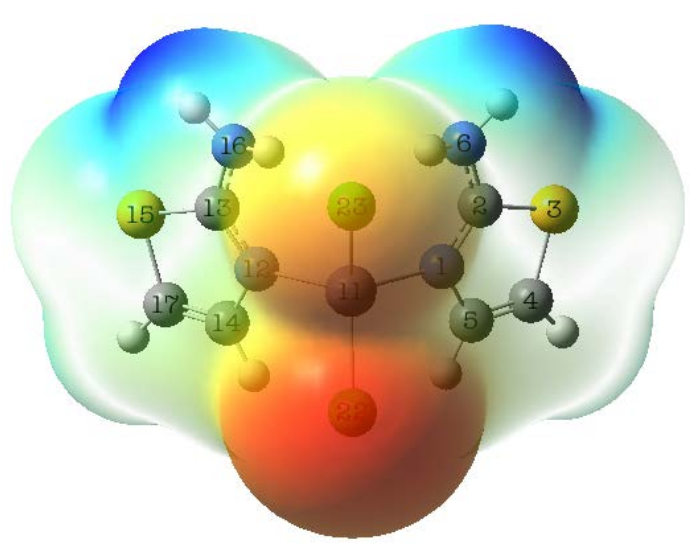

Figure 2. Molecular electrostatic potential mapped on the surface for [ $\left.\mathrm{Zn}(2-\mathrm{Aminothiazole})_{2} \mathrm{Cl}_{2}\right]$ calculated at the B3LYP/6-31G(d, p) level of theory.

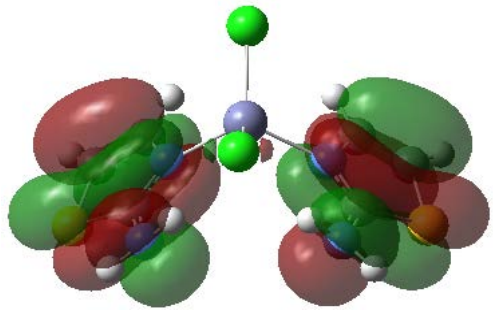

1

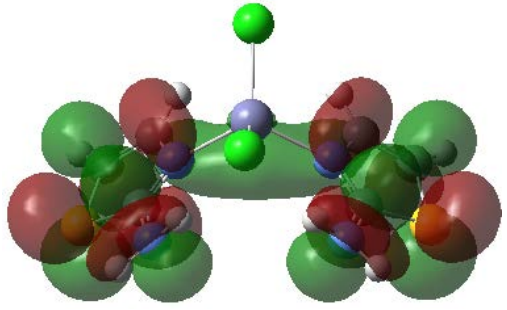

2

Figure 3. Electron distribution of HOMO (Ground state) $\mathbf{- 1}$ and LUMO (First excited state)-2 for [Zn(2-Aminothiazole $\left.)_{2} \mathrm{Cl}_{2}\right] . E_{\mathrm{HOMO}}=-617.491 \mathrm{~kJ} / \mathrm{mol} ; E_{\mathrm{LUMO}}=-86.852 \mathrm{~kJ} / \mathrm{mol} ; \Delta E_{\mathrm{LUMO}-\mathrm{HOMO}}=$ $530.881 \mathrm{~kJ} / \mathrm{mol}$.

\subsection{Vibrational Spectral Analysis}

The vibrational spectra of 2-Aminothiazole and $\left[\mathrm{Zn}(2 \text {-Aminothiazole })_{2} \mathrm{Cl}_{2}\right.$ ] were calculated by DFT with B3LYP functional having extended basis sets 6-31G(d, p). The experimental assignments of IR for several vibrations, IR theoretical and relative intensities are reported in Table 3.

Frequencies recorded experimentally for 2-Aminothiazole and for [ $\left.\mathrm{Zn}(2 \text {-Aminothiazole })_{2} \mathrm{Cl}_{2}\right]$ in far IR were compared with the calculated frequencies obtained by DFT/B3LYP methods with 6-31G(d, p) basis sets. In order to improve the calculated values in agreement with the experimental values, it is necessary to scale down the calculated harmonic frequencies. After scaling, the theoretical frequencies will match well with the experimental ones. These assignments are important to understand the molecular structureand biological activity of the title molecule. Any discrepancies noted between the observed and the calculated wavenumbers due to the fact that the calculations were actually performed on single (isolated) molecules in the gaseous state. Thus some reasonable deviations from the experimental values seem to be justified.

\subsection{Thermodynamic Properties}

The calculated several thermodynamic parameters are presented in Table 4. The zeropoint vibrational energies, rotational constants, rotational temperature, thermal energy, molar capacity at constant volume and entropy were calculated by B3LYP/6-31G(d, p) in gas and in water phase.

\section{Conclusion}

The geometry of [Zn(2-Aminothiazole $)_{2} \mathrm{Cl}_{2}$ ] was optimized with HF and DFT/B3LYP methods using 6-31G(d, p) basis set. The results calculated methods indicate that B3LYP is superior to HF, probably because of the fact that the former includes some of the effects of electron correlation. The complete molecular structural parameters and thermodynamic properties of the optimized geometry of the compound were obtained from $a b$ initio and 
Table 3. Experimental and calculated characteristic frequencies $\left(\mathrm{cm}^{-1}\right)$, IR intensity and probable assignments of 2-Aminothiazole and [ $\left.\mathrm{Zn}(2-\text { Aminothiazole })_{2} \mathrm{Cl}_{2}\right]$.

\begin{tabular}{|c|c|c|c|c|c|c|}
\hline \multicolumn{3}{|c|}{ 2-Aminothiazole } & \multicolumn{3}{|c|}{ [Zn(2-Aminothiazole) ${ }_{2} \mathrm{Cl}_{2}$ ] } & \multirow[t]{3}{*}{ Assignments $^{\mathrm{b}}$} \\
\hline \multirow{2}{*}{$\begin{array}{c}\text { Experimental } \\
\text { frequencies }[17]^{\mathrm{a}}\end{array}$} & \multicolumn{2}{|c|}{ B3LYP/6-31G(d, p) } & \multirow{2}{*}{$\begin{array}{l}\text { Experimental } \\
\text { frequencies [18] }\end{array}$} & \multicolumn{2}{|c|}{ B3LYP/6-31G(d, p) } & \\
\hline & Scaled & $I_{A b s}$ & & Scaled & $I_{A b s}$ & \\
\hline- & 3686 & 29 & - & 3683 & 96 & $v_{\text {assym }(\mathrm{NH})} ;\left(\mathrm{NH}_{2}\right)$ \\
\hline $3413 w$ & 3569 & 37 & - & 3396 & 532 & $N_{\text {sym(NH) }} ;\left(N_{2}\right)$ \\
\hline $3293 w$ & 3224 & 10 & - & 3249 & 17 & $v_{(C-H)}$ \\
\hline $1764 s$ & 1653 & 186 & - & 1675 & 366 & $\delta_{b\left(N H_{2}\right)} ; \quad v_{(C=N)}$ \\
\hline $1629 m$ & 1588 & 73 & - & 1595 & 35 & $\delta_{b\left(\mathrm{NH}_{2}\right)} ; \quad v_{(\mathrm{C}=N)} ; v_{(\mathrm{C}=\mathrm{C})}$ \\
\hline $1527 \mathrm{~m}$ & 1544 & 52 & - & 1572 & 216 & $\delta_{b\left(N H_{2}\right)} ; \quad v_{(C-N)} ; v_{(C=C)}$ \\
\hline $1361 s$ & 1359 & 44 & - & 1390 & 83 & Rband; $v_{(\mathrm{C}-H)}$ \\
\hline 1327 s & 1305 & 54 & - & 1386 & 118 & Rband; $v_{(C-H)}$ \\
\hline $1277 \mathrm{~ms}$ & 1243 & 24 & - & 1247 & 65 & $\delta_{t\left(N H_{2}\right)} ; \quad v_{(C-N)} ; v_{(C-H)}$ \\
\hline $1070 s$ & 1054 & 47 & - & 1081 & 91 & $\delta_{t\left(\mathrm{NH}_{2}\right)} ; \quad$ Rband \\
\hline $769 \mathrm{~s}$ & 754 & 12 & - & 759 & 14 & Rband; $v_{(\mathrm{C}-S)}$ \\
\hline $709 s$ & 700 & 13 & - & 714 & 32 & Rband \\
\hline $695 \mathrm{~ms}$ & 650 & 46 & - & 647 & 126 & Rband; $v_{(C-S)}$ \\
\hline $661 v s$ & 644 & 158 & - & 611 & 24 & Rband \\
\hline $542 s$ & 556 & 61 & - & 525 & 65 & Rband; $\delta_{w\left(\mathrm{NH}_{2}\right)}$ \\
\hline $517 \mathrm{~ms}$ & 510 & 103 & - & 519 & 30 & $\delta_{w\left(N H_{2}\right)}$ \\
\hline- & 292 & 36 & 400 & 399 & 32 & $\delta_{r\left(\mathrm{NH}_{2}\right)}$ \\
\hline- & - & - & - & 381 & 137 & $\delta_{t\left(N H_{2}\right)}$ \\
\hline- & - & - & 300 & 330 & 63 & $v_{(Z n-C l)}$ \\
\hline- & - & - & 290 & 261 & 17 & $v_{(Z n-C l)}$ \\
\hline- & - & - & 225 & 216 & 22 & $v_{(Z n-N)}$ \\
\hline- & - & - & 185 & 197 & 2 & $v_{(Z n-N)}$ \\
\hline- & - & - & 168 & 163 & 13 & Rband; $\delta_{r\left(\mathrm{NH}_{2}\right)}$ \\
\hline
\end{tabular}

Scale factors of 0.9613 for calculated frequencies with B3LYP/6-31G(d, p). (a) s: strong; $m$ : medium; w: weak; vw: very weak; (b) v: stretching; ss: symmetric; ass: asymmetric; $\delta_{b}$ : bending; $\delta_{r}$ : rocking; $\delta_{w}$ : wagging; $\delta_{t}$ : twisting; Rband: ring deformation. $I_{A b s}$ : Theoretical infrared intensities.

Table 4. Theoretically computed thermodynamic properties for [Zn(2-Aminothiazole $\left.)_{2} \mathrm{Cl}_{2}\right]$.

\begin{tabular}{ccc}
\hline Parameters & In gas phase B3LYP/6-31G(d, p) & In water phase B3LYP/6-31G(d, p) \\
\hline Zero point vibration energy $\left(\mathbf{k c a l} \cdot \mathbf{m o l}^{-\mathbf{1}}\right)$ & 43.54426 & 93.82020 \\
Rotational constants $(\mathrm{GHz})$ & & \\
A & 5.28270 & 0.38260 \\
B & 3.38410 & 0.25372 \\
C & 2.06675 & 0.23002 \\
\hline
\end{tabular}




\section{Continued}

Rotational temperature (K)

A

0.25353

0.01836

0.16241

0.01218

C

0.09919

0.01104

Thermal energy $\left(\mathrm{kcal} \cdot \mathrm{mol}^{-1}\right)$

Total
Translational
Rotational
Vibrational

47.008

105.168

0.889

0.889

0.889

0.889

Vibrational

45.230

103.391

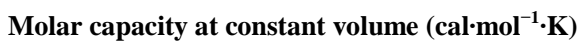

$\begin{array}{ccc}\text { Total } & 20.764 & 62.137 \\ \text { Translational } & 2.981 & 2.981 \\ \text { Rotational } & 2.981 & 2.981 \\ \text { Vibrational } & 14.802 & 56.176 \\ \left.\text { tropy (cal·mol }{ }^{-1} \cdot \mathbf{K}\right) & & \\ \text { Total } & 74.613 & 145.755 \\ \text { Translational } & 39.718 & 43.312 \\ \text { Rotational } & 26.567 & 33.931 \\ \text { Vibrational } & 8.328 & 68.512\end{array}$

DFT calculations. The vibrational frequencies of the fundamental modes of the compound were precisely assigned, analyzed and the theoretical results were compared with the experimental vibrations. The close agreement was observed between the experimental and scaled frequencies obtained using the basis set 6-31G(d, p). HOMO-LUMO studies reveal the intra molecular charge transfer through conjugated system. The Mulliken charges calculated by B3LYP/6-31G(d, p) method were reported. Information about the size, charge density distribution and structure-activity relationship of the $\left[\mathrm{Zn}(2-\mathrm{Aminothiazole})_{2} \mathrm{Cl}_{2}\right]$ molecule was obtained by mapping electron density isosurface with electrostatic potential.

\section{References}

[1] Manju, Kishore, D. and Kumar, D. (2011) Cadmium and Tin Complexes of Schiff-Base Ligands. Journal of Coordination Chemistry, 64, 2130-2156. http://dx.doi.org/10.1080/00958972.2011.590193

[2] Sigel, H. and McCormick, D.B. (1970) Discriminating Behavior of Metal Ions and Ligands with Regard to Their Biological Significance. Accounts of Chemical Research, 3, 201-208. http://dx.doi.org/10.1021/ar50030a004

[3] Dixon, M. and Webb, E.C. (1964) Enzyme Inhibitors. In: Enzymes, Academic Press, New York, 315-359.

[4] Raman, N., Johnson Raja, S., Joseph, J. and Dhaveethu Raja, J. (2007) Synthesis, Spectral Characterization and DNA Cleavage Study of Heterocyclic Schiff Base Metal Complexes. Journal of the Chilean Chemical Society, 52, 11381141. http://dx.doi.org/10.4067/S0717-97072007000200004

[5] Neelakantan, M.A., Marriappan, S.S., Dharmaraja, J., Jeyakumar, T. and Muthukumaran, K. (2008) Spectral, XRD, SEM and Biological Activities of Transition Metal Complexes of Polydentate Ligands Containing Thiazole Moiety. Spectrochimica Acta Part A: Molecular and Biomolecular Spectroscopy, 71, 628-635. http://dx.doi.org/10.1016/j.saa.2008.01.023

[6] Frisch, M.J., Trucks, G.W., Schlegel, H.B., Scuseria, G.E., Robb, M.A., Cheeseman, J.R., Montgomery Jr., J.A., Vreven, T., Kudin, K.N., Burant, J.C., Millam, J.M., Iyengar, S.S., Tomasi, J., Barone, V., Mennucci, B., Cossi, M., Scalmani, G., Rega, N., Petersson, G.A., Nakatsuji, H., Hada, M., Ehara, M., Toyota, K., Fukuda, R., Hasegawa, J., Ishida, 
M., Nakajima, T., Honda, Y., Kitao, O., Nakai, H., Klene, M., Li, X., Knox, J.E., Hratchian, H.P., Cross, J.B., Bakken, V., Adamo, C., Jaramillo, J., Gomperts, R., Stratmann, R.E., Yazyev, O., Austin, A.J., Cammi, R., Pomelli, C., Ochterski, J.W., Ayala, P.Y., Morokuma, K., Voth, G.A., Salvador, P., Dannenberg, J.J., Zakrzewski, V.G., Dapprich, S., Daniels, A.D., Strain, M.C., Farkas, O., Malick, D.K., Rabuck, A.D., Raghavachari, K., Foresman, J.B., Ortiz, J.V., Cui, Q., Baboul, A.G., Clifford, S., Cioslowski, J., Stefanov, B.B., Liu, G., Liashenko, A., Piskorz, P., Komaromi, I., Martin, R.L., Fox, D.J., Keith, T., Al-Laham, M.A., Peng, C.Y., Nanayakkara, A., Challacombe, M., Gill, P.M.W., Johnson, B., Chen, W., Wong, M.W., Gonzalez, C. and Pople, J.A. (2004) Gaussian 03, Revision B.04. Gaussian, Inc., Wallingford.

[7] Lee, C.T., Yang, W.T. and Parr, R.G. (1988) Development of the Colle-Salvetti Correlation-Energy Formula into a Functional of the Electron Density. Physical Review B, 37, 785-789. http://dx.doi.org/10.1103/PhysRevB.37.785

[8] Becke, A.D. (1993) Density_Functional Thermochemistry. III. The Role of Exact Exchange. The Journal of Chemical Physics, 98, 5648-5652. http://dx.doi.org/10.1063/1.464913

[9] Parr, R.G. and Yang, W. (1989) Density-Functional Theory of Atoms and Molecules. Vol. 16, Oxford University Press, Oxford.

[10] Mulliken, R.S. (1955) Electronic Population Analysis on LCAO-MO Molecular Wave Functions. I. The Journal of Chemical Physics, 23, 1833-1840. http://dx.doi.org/10.1063/1.1740588

[11] Onsanger, L. (1936) Electric Moments of Molecules in Liquids. Journal of the American Chemical Society, 58, 14861493. http://dx.doi.org/10.1021/ja01299a050

[12] HyperChem for Windows, Release 5.1, HyperCube, Inc.

[13] Varetto, U. (2000) MOLEKEL Version. Swiss National Supercomputing Centre, Lugano.

[14] Macíček, J. and Davarski, K. (1993) Structure of Bis (2-Aminothiazole) Dichlorozinc (II). Acta Crystallographica Section C: Crystal Structure Communications, 49, 592-593. http://dx.doi.org/10.1107/S0108270192010382

[15] Politzer, P., Laurence, P.R. and Jayasuriya, K. (1985) Molecular Electrostatic Potentials: An Effective Tool for the Elucidation of Biochemical Phenomena. Environmental Health Perspectives, 61, 191. http://dx.doi.org/10.1289/ehp.8561191

[16] Sastri, V.S. and Perumareddi, J.R. (1997) Molecular Orbital Theoretical Studies of Some Organic Corrosion Inhibitors. Corrosion Science, 53, 617-622. http://dx.doi.org/10.5006/1.3290294

[17] http://www.hanhonggroup.com/ir/ir_en/B41028.html

[18] Davarski, K., Macicek, J. and Konovalov, L. (1996) Far IR Spectra and Structures of Zn(II) Complexes of 2-Aminothiazoles. Journal of Coordination Chemistry, 38, 123-134. http://dx.doi.org/10.1080/00958979608022697 